\title{
Establishment and development of Kosovo Correctional Service during 1999 -2013
}

\author{
Resmi Hoxha, Mr.sc. \\ PhD Candidate at Tirana European University, Albania. \\ resmi.hoxha@live.com
}

DOI:10.5901/mjss.2014.v5n19p505

\begin{abstract}
Although a new country from the aspect of the establishment and development of Correctional Institutions, yet the Republic of Kosova has a very intensive and interesting flow, commencing from the acts and institutions of former Yugoslavia, Serbia, UN Protectorate and lately after the independence in 2008, it has the new legislation and institutions of Republic of Kosova. The establishment and development of Institutions of Correctional Service of Kosova, in the after war period of 1999, was part of the legislative transition which the Republic of Kosova has undergone during the international administration based on Resolution 1244 of UN Security Council. The process of reformation of the Correctional Institution of Kosova after the war was one of the fields where along with the efforts to build a new concept of the functioning of the Correctional Service of Kosova, there were efforts also to work on unifying the rules of procedure in compliance with the international norms and standards. The development of the Correctional Service of Kosova, from the chronological Aspect has undergone four periods of development under the supervision and support of the international community such as: First period includes the period of interim administration of the Institutions of Kosovo Correctional Service by KFOR, from June- October 1999. Second period begins with UNMIK, taking over from KFOR the authority for the organization and functioning of the Kosovo Correctional Service in October 1999. Third period begins with shifting of the authority from UNMIK to Kosovo Government, respectively from the UNMIK Department of Justice to the Ministry of Justice of the Government of Kosovo, which took place in October 2006. Fourth period begins with the Declaration of Independence of Kosovo in 2008, where the completion of the legal infrastructure and the promulgation of the sublegal acts for the functioning and the work of the correctional institutions in Kosovo. At the end of the war in 1999, Kosovo correctional facilities were destroyed from the aspect of the infrastructure and all other aspects. These institutions were rebuilt initially with the assistance of the international community- UNMIK, and later on with the investments by the Government of Kosova. New facilities were built as well. Now, six years after its independence, Kosova pledged to follow its path towards EU, which enabled the Correctional Institutions to rapidly develop with the purpose of fulfilling international standards for joining $E U$ and other international structures.
\end{abstract}

Keywords: Kosova Correctional Institutions, legislation, Constitution, International community-UNMIK.

\section{INTRODUCTION}

The establishment and development of the institutions of the Kosovo Correctional Service since the after war period in 1999, was part of a legal transition that Republic of Kosova went through during the international administration based on the UN Security Council Resolution 1244.

The process of reforming the institutions of the Kosovo Correctional Service after the war was one field where along with the efforts to build a new concept of the functioning of the institutions of Kosovo Correctional Service, work was concentrated and actions were taken also on unifying the work regulations with the international norms and standards. Resolution 1244 and the Constitutional Framework for Provisional Self-Government in Kosovo have determined UNMIK's authority to extend its powers in the whole territory of Kosovo where the Kosovo Correctional Service facilities have been established.

It's worth mentioning that difficulties arose for UNMIK in administering all Detention and Correctional Centers of Kosovo Correctional Service. Looking from the chronological aspect, the efforts for organization and functioning of the Kosovo Correctional Service may be divided into four periods:

First period includes the period of interim administration of the Institutions of Kosovo Correctional Service by KFOR, from June- October 1999. 
Second period begins with UNMIK, taking over from KFOR the authority for the organization and functioning of the Kosovo Correctional Service in October 1999.

Third period begins with shifting of the authority from UNMIK to Kosovo Government, respectively from the UNMIK Department of Justice to the Ministry of Justice of the Government of Kosovo, which took place in October 2006.

Fourth period begins with the Declaration of Independence of Kosovo in 2008, where the completion of the legal infrastructure and the promulgation of the sublegal acts for the functioning and the work of the correctional institutions in Kosovo. Further we will go through all the periods of the development and the functioning of the correctional institutions in Kosovo.

\section{DEVELOPMENT}

First period: The organization and the functioning of the Correctional Service under KFOR administration

With the commencement of the NATO bombings (Clinton: 2004), new arrests took place and a large number of citizens were abducted with no reason and no court verdict from the streets and the same were placed in the correctional institutions. They have undergone inhuman treatment and witnesses talk about the physical and psychological tortures they suffered. Additionally they were given only one meal within 24 hours just so they can survive. Some of them being unable to face this situation have even committed suicide by hanging themselves and openly telling to the people of the regime that it is better if they are executed than being tortured in the most inhuman manner. It should be mentioned that a number of them were executed just because they asked for a better treatment from the people of the regime.

At the end of the war, Kosovo correctional facilities were destroyed from the aspect of the infrastructure and all other aspects. It is worth mentioning that the history of the penitentiary system is an inseparable part of the overall history of a state, therefore Kosovo Institutions present no exclusion (Sadiku: 2010). Initially with the entry of KFOR (Halbauer: 2012) forces in Kosovo, all the institutions: Detention and Correctional Institutions, were under the KFOR administration and management. They were initially involved on the physical security of the facilities and their management. During this period there were still staff of Serb nationality who were working for the Correctional Institutions and at that time KFOR allowed them to withdraw and leave for Serbia.

Second period: The organization and the functioning of the Correctional Service under UNMIK administration

Kosovo Correctional Service was established in November 1999 by UNMIK (United Mission in Kosovo) within the first justice pillar as the reserved competency of the SRSG (Special Representative of Secretary General) and supported by the local staff immediately started its work in November 1999 (MJK)1.

Kosovo Correctional Service inherited a dysfunctional infrastructure but which was consolidated and made functional fulfilling the Kosovo requirements for detention and serving sentences, since its beginnings and up to this phase when visible infrastructural improvements have taken place, to include the increase the work quality level. Kosovo Correctional Service initially established and the Detention Center in Prizren to continue further with the consolidation of the infrastructure of correctional facilities in Dubrava, Gjilan, Lipjan, Peja, Mitrovica and all other center in Kosovo.

Kosovo Correctional Service under the international monitoring has continuously recruited local correctional staff in order to fulfill the needs a functional service, which under this conditions faced many challenges, not leaving behind the aspects of work subculture in prisons (Kauffman:1998). Kosovo Correctional Service was built up based on the international criteria and standards, similar to the most advanced correctional systems in Europe, thanks to the international staff which brought their best practices from their countries. The Kosovo Correctional Service since its establishment is part of the overall developments of the circumstances in the after-war Kosovo, which went through various challenges and difficulties during all the transition phase.

UNMIK Regulation 1999/24 was the applicable legal basis for the work of the correctional institutions, which enabled the application of the Law on Execution of Criminal Sanctions of 1977. Additionally, the European Prison Rules as well as international standards were directly applicable in the Kosovo Correctional Service. In 2001, the legal infrastructure was completed (KC framework); setting a clearer basis between PISG (Provisional Institutions of Self-Government of Kosovo.) and UNMIK, yet the development of the Kosovo Correctional Service remained as reserved competency of SRSG, 
respectively under the management of the Criminal Division of the Justice Department. During the time when Kosovo Correctional Service was a reserved competency, the local staff continued with efforts to increase the professional and management capacities and the preparations to take over the competencies and responsibilities from internationals who until that time managed the Kosovo Correctional Service.

Third period: The transfer of competencies from UNMIK to the Ministry of

Justice, the Government of Kosovo

The third period begins with the transfer of competencies from UNMIK to the Government of Kosovo. In 2005- UNMIK Regulation no.2005/53 set the legal basis for the establishment of the Ministry of Justice stipulating the initial competencies. Ministry of Justice became functional in March 2006. At a later stage in 2006, UNMIK Regulation no.2006/26, dated 27th April 2006, expanded the competencies of the Ministry of Justice to include the competency over the Correctional Service, excluding the command over the emergency situations at Dubrava Correctional Center until the end of the UNMIK executive mission. After this phase Kosovo Correctional Service recruited entirely new management comprised of local staff and it developed independently from UNMIK, under the authority of the Ministry of Justice. This period of transfer of competencies lasted until the declaration of independence of Kosovo in 2008 and it was of outmost interest for the continuation of the professional operation of the correctional facilities (Dreshaj:2010).

Fourth period: Independence of the Correctional Service and the progress of Institutions for execution of criminal sanctions

With the declaration of independence of Kosovo (Independence of Kosovo was declared on 17th February 2008) and with the adoption of the Constitution of Republic of Kosovo (Constitution of Republic of Kosovo entered into force on 15th June 2008), all the competencies in the field of justice system and the correctional service were transferred under the management of the local institutions and under the management and supervision of the ministry of Justice.

The functions of the Kosovo Correctional Service are stipulated on the Constitution of Republic of Kosovo, the Criminal Code of Kosovo, the Law on Execution of Criminal Sanctions, Juvenile Justice Code, Law on Pardon, Ministry of Justice sublegal acts (It includes the Administrative Directives, Rules of Procedure, Internal Rules and House Rules), International Conventions and the Universal Declaration on Human Rights. Based on the above provisions, the Kosovo Correctional Service has undertaken the following actions: the organization, implementation and supervision of the execution of the jail sentence and long-term jail sentences; the organization, implementation and supervision of the execution of the juvenile sentence and the educational-correctional measures; the organization, implementation and supervision of the execution of the detention measures; organization of the programs geared towards the correction and social reintegration of the offenders, preparing them for the release and facilitating their reintegration in the family and society (Dreshaj:2010); recruitment, training and assessment of staff of the Kosovo Correctional Service; preparation of analyses, statistics and information on the Correctional Service; undertaking the necessary measures to ensure the data protection related to the Kosovo Correctional Service.

\section{CONCLUSION}

Kosovo Correctional Service after the calendar year 1999, under the supervision and contribution of the international community has marked a significant progress in the spirit of a humane penitentiary system. This significant progress has been marked also on the reports prepared by many international and local entities.

The international community assisted the Kosovo Correctional Service by, renovating all the correctional detention facilities, building new capacities for accommodating the offenders; building staff capacity by in country training and training abroad, increasing the technical and security capacities for a more successful work. The establishment of database with the data on the offenders, staff and other data necessary for a successful work, was of outmost importance for the Kosovo Correctional Service.

During this period of international administration the legal infrastructure was established to include also the sublegal acts and Standard Operating Procedures; all of which are based on the most advanced international standards. This enabled the cooperation with other countries and the extradition of the offenders to various countries.

In line with the requirements stemming out from the legal infrastructure, the Correctional Service of Kosova, has established also the necessary institutions for the safety and treatment of prisoners in compliance with the international laws and standards. It is worth mentioning that the High Security Prison was constructed, to enable a higher security for the offenders who are qualified with high and very high risk scale. 
Despite all the efforts and achievements, there were also many difficulties since the Kosovo Correctional Service lacks the necessary juvenile facility who are sentenced with educational-correctional measure. Additionally, there is a lack of a facility to treat offenders with psycho-physical deficiencies. The lack of these institutions represents a big problem in equal treatment of offenders and makes it difficult to be in compliance with the international norms and standards.

With the declaration of independence of Kosovo new circumstances were created for transfer of full competencies in management of the correctional institutions in Kosovo. In this context the legal infrastructure was amended to regulate the functioning of the correctional institutions. In compliance with the legislation other sublegal acts are adopted as well as Rules of Procedure for the Kosovo Correctional Service.

The correctional Service established its identity by changing the uniform and emblem, by functionalizing the promotion system and by partially equipping staff with weapons for security purposes.

\section{Bibliography}

Bajgora, Ali.: Some characteristics of crime and crime policy in Kosovo, Pristina, 2001.

Clinton, Bill, (2004), My life, Knopf Doubleday Publishing Group, Washington.

Dreshaj.Arben, (2010), "The role and importance of the correctional services in the social reintegration of offenders", Litografia, Gjakove.

Elezi, I. and Hysi, Vasilika (2001): Criminal Policy, Tirana.

Gashi, Rexhep (2001). : Execution of jail sentence in Albania, Pristina.

Halili, Ragip (1985). : Criminal Sanctions according to Customary Law in Kosovo, Pristina.

Halili, Ragip (1973): Criminal sanctions as measures for social protection, Përparimi-9,Pristina.

Halili, Ragip (1970): The purpose and reason of sentence for the murder crime, Përparimi-6, Pristina.

Halili, R:Execution of criminal sanctions against juveniles, Përparimi-10, Pristina,1970.

Kauffman, Kelsey, (1998), Prison officers and their world, Harvard University Press, London

Major General Volker Halbauer (2012), Kosovo Force, Key Facts and Figures, Brussels.

Omari, Luan (2002), State of Law, Tirana,

Ramadan, M.(2003): Penology and the system of execution of criminal sanctions, Novi sad-Beograd.

Sadiku, Isuf, (2010), Execution of criminal sanctions in light of latest international documents, Papirus Print, Gjilan.

Sahiti, Enver (2005) "Criminal Procedure Law", Pristina.

Salihi, Ismet, (2003). Criminal Law, Pristina,

Salihi, Ismet (2005): Juvenile Justice, Pristina. 